\title{
Human Gene Mapping 10.5
}

Oxford Conference (1990): Update to the Tenth International Workshop on Human Gene Mapping

S. Karger $\bullet$ Medical and Scientific Publishers

Basel $\bullet$ München $\bullet$ Paris $\bullet$ London $\bullet$ New York $\bullet$ New Delhi $\bullet$ Bangkok $\bullet$ Singapore $\bullet$ Tokyo $\bullet$ Sydney

All rights reserved.

No part of this publication may be translated into other languages, reproduced or C Copyright 1990 by S. Karger AG, P.O. Box, CH-4009 Basel (Switzerland)

utilized in any form or by any means, electronic or mechanical, including photo- Printed in Switzerland by Thür AG Offsetdruck, Pratteln copying, recording, microcopying, or by any information storage and retrieval system, without permission in writing from the publisher or, in the case of photocopying, direct payment of a specified fee to the Copyright Clearance Center (see 'Information for Readers and Subscribers').

Human Gene Mapping 10.5

Oxford Conference (1990)

Update to the Tenth International Workshop on Human Gene Mapping

Cytogenetics and Cell Genetics Vol. 55,Nos. 1-4,1990

KARGER

Received for publication December 27, 1990

Basel $\bullet$ München $\bullet$ Paris $\bullet$ London $\bullet$ New York $\bullet$ New Delhi $\bullet$ Bangkok $\bullet$ Singapore $\bullet$ Tokyo $\bullet$ Sydney

Published by Cytogenetics and Cell Genetics

under the title

Human Gene Mapping 10.5

viii + 786 pp., 41 fig., 83 tab., 1990

Publisher: S. Karger AG

P.O. Box

CH-4009 Basel (Switzerland)

Copies of 'Human Gene Mapping 10.5' and of earlier Mapping Reports can be ordered only through the publisher, S. Karger AG, at the above address or in the United States from:

S. Karger Publishers, Inc. 26 West Avon Road P.O. Box 529 Farmington,CT 06085

Library of Congress Catalog Card Number 73-644001

Copyright $(1990$ by

S. Karger AG, P.O. Box, 4009 Basel (Switzerland) Printed in Switzerland by Thür AG Offsetdruck, Pratteln ISBN 3-8055-5381-1

HGM10.5 UK Executive Committee

Sir Walter Bodmer (Chair)

Ellen Solomon (Co-Chair)

Tim Bishop Martin Bobrow Ian Craig Kay Davies John Edwards 
Cancer Research Campaign of the United Kingdom

Amersham International Apple Computers (UK) Beckman Instruments (UK) British Bio-Technology

Malcolm Ferguson-Smith Peter Goodfellow Peter Harper Sue Povey Michael Probert

Granting Agencies

Medical Research Council of Canada

Corporate Sponsors

Hewlett-Packard

S.KargerAG

Sitka

Chris Rawlings Bette Robson Nigel Spurr

Veronica van Heyningen Bob Williamson

National Institutes of Health of the United States

Sun Microsystems (UK) Sybase Inc. WordPerfect Corporation

Simon Earthrowl Lyndon Gray Saki Hajnal David Harley John Hopkins Allan Isted

Management and Administration

Ian Craig Michael Probert

Yumiko Ishikawa Elinor Tolley

HGM10.5 Computing Team and Consultants

Chris Rawlings (Project Manager)

Mary Jennings Gavin Litchfield Robert Mangan Lowie Massey Maz Moazzam

Barry Pettigrew Ali Rahmanzadeh Mike Roch Mark Seiden Julia White

Genome Data Base Development Team and Consultants

Richard Lucier (Project Manager)

Peter Pearson (Scientific Director)

Diane Hinton (HHMI Genome Program Manager)

Chris Brunn Peter Cartwright Tom Emmel Kay Gottesman John Johnston Lita Kearney Steve Bryant Abida Ghori Michelle Kirby

Steve Kelley Fran Lewitter Bonnie Maidak Dave Marquette Glenn Mason Karen Phipps

Assistants to the Computing Team

Jeremy Martinson Jian Peng Jeremy Rowntree

Francois Schiettecatte Debbi Schneider Marv Schneider Leonie Stranc Ted Ying

Avril Smith Mike Williams

VI

ELEVENTH INTERNATIONAL WORKSHOP ON HUMAN GENE MAPPING

The Eleventh International Workshop on Human Gene Mapping will be held

from 18-22 August 1991 in London, UK

The structure of the meeting will represent a transition from that of earlier Workshops. There will be meetings of individual Chromosome Committees and interest groups during the first two days, to include talks and workshops on such items as the genetic map, physical map, mapping panels, probe resources and loci of particular interest. Over the final two days, there will be open discussion meetings on topics such as physical mapping, genetic mapping, ethics, informatics and plenary scientific talks by invited speakers on major issues in gene mapping.

Attendance will be limited and priority given to authors of accepted abstracts. The deadline for receipt of abstracts will be 15 April 1991. 
Recipients of this notice by mail are included in the current circulation list for announcements and further information about the Workshop. Colleagues and others who wish to be placed on the mailing list should contact:

Jane Crowther

HGM 11 Office

Imperial Cancer Research Fund

PO Box 123

Lincoln's Inn Fields

London WC2A 3PX

Tel.: 44-71-269-3389 Fax:44-71-430-1787 E-mail: HGMINFO $\delta>$ UK.AC.ICRF.HGM

\section{Table of Content}

\section{Introduction}

Sir Walter Bodmer

Overview of HGM10.5

I. W. Craig and C. J. Rawlings

production of the HGM10.5 Report

C. J. Rawlings 3

The 1990 catalog of mapped genes and report of the nomenclature committee

P. J. McAlpine, L. C. Stranc, C. Boucheix and T. B. Shows 5

Report of the committee on the genetic constitution of chromosome 1

G. A. Bruns and N. C. Dracopoli

77

Report of the committee on the genetic constitution of chromosome 2

N. K. Spurr and M. Leppert 86

Report of the committee on the genetic constitution of chromosome 3

S. L. Naylor and B. Carritt 92

Report of the committee on the genetic constitution of chromosome 4

J. C. Murray and G. B. van Ommen

97

Report of the committee on the genetic constitution of chromosome 5

D. T. Bishop and C. Westbrook Ill

Report of the committee on the genetic constitution of chromosome 6

A. Ziegler, L. L. Field and A. Y. Sakaguchi 118

Report of the committee on the genetic constitution of chromosome 7

L. C. Tsui and M. Farrall 122

Report of the committee on the genetic constitution of chromosome 8

H. Donis-Keller and V. Buckle

128

Report of the committee on the genetic constitution of chromosome 9

S. Povey and D. Goudie 136

Report of the committee on the genetic constitution of chromosome 10

N. E. Simpson and H. Cann 142

Report of the committee on the genetic constitution of chromosome 11

C. Junien and V. van Heyningen 151

Report of the committee on the genetic constitution of chromosome 12

I. W. Craig and W. O. McBride

170

Report of the committee on the genetic constitution of chromosome 13

A. M. Bowcock and R. T Taggart 177

Report of the committee on the genetic constitution of chromosome 14

D. W. Cox, Y. Nakamura and T. Gedde-Dahl Jr 183

Report of the committee on the constitution of chromosome 15

T. A. Donlon and S. Malcolm 189

Report of the committee on the constitution of chromosome 16

S. T. Reeders, C. E. Hildebrand and G. R. Sutherland

Report of the committee on the constitution of chromosome 17

E. Solomon and D. H. Ledbetter 198

$\mathrm{Vl}$

Table of Content 
Report of the committee on the constitution of chromosome 18

M. M. Le Beau and A. H. M. Geurts van Kessel 216

Report of the committee on the constitution of chromosome 19

H. H. Ropers and M. A. Pericak-Vance 218

Report of the committee on the constitution of chromosome 20

K. H. Grzeschik and M. H. Skolnick 229

Report of the committee on the constitution of chromosome 21

D. R. Cox and N. Shimizu 235

Report of the committee on the constitution of chromosome 22

B. S. Emanuel and B. R. Seizinger 245

Report of the committee on the constitution of the $\mathrm{X}$ chromosome

K. E. Davies, J. L. Mandel, A. P. Monaco, R. L. Nussbaum and H. F. Willard

Report of the committee on the constitution of the Y chromosome

J. Weissenbach and P. Goodfellow 314

Report of the committee on clinical disorders and chromosomal deletion syndromes

J. Frézal, A. Schinzel and M. Baule 321

Report of the committee on chromosome changes in neoplasia

F. Mitelman, Y. Kaneko, and J. M. Trent 358

Report of the committee on linkage and gene order

B. J. B. Keats, S. L. Sherman and J. Ott 387

Report of the committee on the mitochondrial genome

D.C.Wallace 395

Report of the committee on comparative gene mapping

S. J. O'Brien and J. A. Marshall Graves 406

Report of the comparative subcommittee for human and mouse homologies

M. T. Davisson, P. A. Lalley, J. Peters, D. P. Doolittle, A. L. Hillyard, and A. G. Searle 434

Report of the DNA committee and catalogues of cloned and mapped genes and DNA polymorphisms

R. Williamson, A. Bowcock, K. Kidd, P. Pearson, J. Schmidtke, H. S. Chan, M. Chipperfield, D. N. Cooper, J. Hewitt,

R Lewitter, B. Maidak, M. Quitt, F. Ricciuti, R. Track 457

Report of the informatics committee

C. J. Rawlings and R. E. Lucier 779

Participants

Names and Addresses 783

How to cite this report and its content:

When referring to this report as an entity in text, it should be cited as: Human Gene Mapping 10.5 (1990). The complete citation for reference list is: Human Gene Mapping 10.5 (1990): Update to the Tenth International Workshop on Human Gene Mapping. Cytogenet Cell Genet 55:1-785 (1990).

Committee reports should be cited according to author names as usual. The complete citation for reference lists is: Authors, title of report, Human Gene

Mapping 10.5 (1990): Update to the Tenth International Workshop on Human Gene Mapping. Cytogenet Cell Genet 55: (page numbersXií>PÖ). 